\title{
Interaction of Mediterranean Water lenses with Antarctic Intermediate Water off Northwest Africa
}

\author{
Francisco José Machín ${ }^{1}$, Josep L. Pelegrí ${ }^{2}$ \\ ${ }^{1}$ Department of Physics, University of Las Palmas de Gran Canaria, Spain. E-mail: francisco.machin@ulpgc.es \\ ${ }^{2}$ Institut de Ciències del Mar, CSIC, Barcelona, Spain.E-mail: pelegri@icm.csic.es
}

\begin{abstract}
Summary: Mediterranean Water lenses (meddies) in the eastern North Atlantic, north of the Canary Islands, appear to often have their salty and nutrient-poor core accompanied by relatively fresh and nutrient-rich waters on top. We describe several occurrences of freshwater halos and berets for meddies sampled north of the Canary Islands- with instrumented moorings, Argo floats and oceanographic cruises - and identify the source of these fresh anomalies as diluted Antarctic Intermediate Water (AAIW). We propose that this capping takes place off Northwest Africa, as the southward-advected meddy interacts with the northward-advected AAIW. This interpretation is consistent with a simple analysis of the relevant advectivediffusive time scales associated with the passage of meddies under a layer of AAIW, and suggests that meddies may be a mechanism for AAIW export far into the North Atlantic Ocean.
\end{abstract}

Keywords: meddies; Antarctic Intermediate Water; eastern North Atlantic.

Interacción de remolinos de agua mediterránea con Agua Intermedia Antártica al noroeste de África

Resumen: Los Meddies en el Atlántico Norte oriental, al norte de las Islas Canarias, a menudo parecen tener su núcleo salado y pobre en nutrientes acompañado de aguas relativamente frescas y ricas en nutrientes en la parte superior. Se describen varios casos de halos y boinas de agua dulce para meddies muestreados al norte de las Islas Canarias -con instrumentos anclados, perfiladores Argo y campañas oceanográficas- identificando así el origen de estas anomalías frescas como Agua Intermedia Antártica (AIAA) diluida. Proponemos que esta interacción se lleva a cabo en el noroeste de África, cuando el meddy advectado hacia el sur interactúa con el AIAA advectada hacia el norte. Esta interpretación es coherente con un simple análisis de las escalas de tiempo advectivo-difusivas asociadas con el paso de meddies bajo una capa de AIAA, y sugiere que los meddies pueden ser un mecanismo para exportar AIAA hacia el océano interior en el Atlántico Norte.

Palabras clave: meddies; agua intermedia antártica; Atlántico Norte oriental.

Citation/Como citar este artículo: Machín F.J., Pelegrí J.L. 2016. Interaction of Mediterranean Water lenses with Antarctic Intermediate Water off Northwest Africa. Sci. Mar. 80S1: 205-214. doi: http://dx.doi.org/10.3989/scimar.04289.06A

Editor: D. Vaqué.

Received: June 11, 2015. Accepted: November 25, 2015. Published: September 30, 2016.

Copyright: (9) 2016 CSIC. This is an open-access article distributed under the terms of the Creative Commons Attribution (CC-by) Spain 3.0 License.

\section{INTRODUCTION}

The life cycle of salty and warm Mediterranean Water (MW) lenses (meddies) and their net impact on the fluxes of freshwater and heat in the North Atlantic have received thorough attention since their discovery by McDowell and Rossby (1978) near the Bahamas. Meddies have been detected and tracked using passive drifters (e.g. Armi et al. 1988, Bower et al. 1997) and repeated sampling from ships (Armi et al. 1989), their properties have been simulated with rotating tanks in the laboratory (Hedstrom and Armi 1988), and a census of their distribution has been carried out with the help of historical hydrographic data (Richardson et al. 2000). All these studies have taught us a great deal not only about the spatial distribution of meddies, but also about the processes that lead to their formation, propagation and eventual disappearance.

Careful examination of several papers on meddies reveals a curious association between the salt lenses and an anomalously fresh layer on top. Such freshwater meddy berets are visible in data from moored arrays (Siedler et al. 2005), in a long-term study of an individual meddy (Armi et al. 1989), and along a hydrographic section (Tsuchiya et al. 1992), but this characteristic has not yet been investigated. In this 
work we will explore the association between meddies and their freshwater berets in the Canary Basin, north of the Canary Islands, and examine the source and characteristics of these low-salinity waters. A coherent tongue of Antarctic Intermediate Water (AAIW), rich in inorganic nutrients and with salinities below 34.5, stretches along the eastern margin of the North Atlantic (Tsuchiya et al. 1992, Machín et al. 2006). A diluted form of this water mass has been detected beyond the Canary Islands, contributing as much as $50 \%$ to water samples gathered at $32.5^{\circ} \mathrm{N}$ in autumn (Machín and Pelegrí 2009, Machín et al. 2010) and being still perceptible in the Gulf of Cadiz (Louarn and Morin 2011). Our hypothesis is that, as they flow off the coast of Northwest Africa, southward-advected meddies are capable of trapping the northward propagating AAIW on top (Fig. 1). Given the importance of meddies in transporting properties very far from their generation region, their association with AAIW is likely to be an important mechanism for the penetration of this southern water mass into the North Atlantic subtropical gyre.

\section{DATA}

In order to characterize the hydrographic conditions in the Canary Basin, we used temperature, salinity and nutrient data downloaded from the World Ocean Atlas 2005 (WOA05), a database from the U.S. National Oceanic Data Centre (NODC). Additionally, we analysed three specific data sets in order to explore the interaction between meddies and AAIW: two cruises north of the Canary Islands, an instrumented mooring deployed north of the Canary Islands, and two floats from the Argo programme; these three data sets are described next (Table 1).

The hydrographic and nutrient cruise data were collected as part of the field activities of the projects CANIGO (Parrilla et al. 2002) and CANOA (Pastor et al. 2012), aimed at elucidating critical features of the region's large-scale circulation and variability. In January 1997, during the Meteor-37 cruise (R/V Meteor as part of the CANIGO project), a meddy (hereafter M37) was detected near $\left(32.2^{\circ} \mathrm{N}, 12.2^{\circ} \mathrm{W}\right)$ (Fig. $1)$. The velocity field for this cruise was calculated with the inverse model used by Machín et al. (2006). In November 2007, during the Canoa07 cruise (R/V García del Cid as part of the CANOA project), another meddy (hereafter GC07) was observed nearby $\left(31.8^{\circ} \mathrm{N}, 13.3^{\circ} \mathrm{W}\right)$ (Fig. 1). In this case, the associated geostrophic velocity field was calculated relative to the neutral density $\left(\gamma_{\mathrm{n}}\right) 27.922 \mathrm{~kg} \mathrm{~m}^{-3}$ (Jackett and McDougall 1997) located in the lower MW layer. During both

Table 1. - Summary of the meddies analysed, with their dates and the data source.

\begin{tabular}{|l|c|c|}
\hline Date & Meddy name & Source \\
\hline January 1997 & M37 & Meteor-37 \\
\hline November 2007 & GC07 & Canoa07 \\
\hline 1995 & E95 & ESTOC \\
\hline 1996 & E96 & ESTOC \\
\hline $2004-2005$ & F04 & Argo float \\
2007 & F07 & Argo float \\
\hline
\end{tabular}

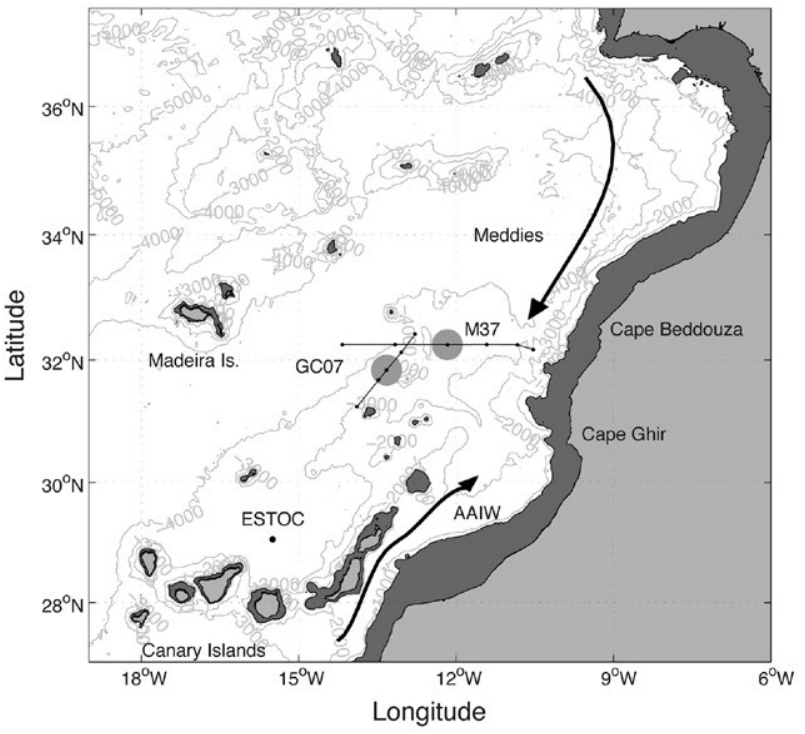

Fig. 1. - Canary Basin north of the Canary Islands, showing the bathymetry and main geographic features; the arrows illustrate the southward mean trajectory of meddies and the northward propagation of AAIW. The hydrographic sections that sampled meddies during the Meteor-37 and Canoa07 cruises are shown together with the approximate location of meddies M37 and GC07, drawn as grey circles, and the position of the ESTOC mooring, drawn as a black

$$
\text { dot. }
$$

cruises, the concentrations of inorganic nutrients were obtained from the analysis of water samples at standard depths.

Velocity, temperature, and salinity were monitored at the European Station for Time Series in the Ocean Canary Islands (ESTOC), located in water depths of $3670 \mathrm{~m}$ at $\left(29.2^{\circ} \mathrm{N}, 15.5^{\circ} \mathrm{W}\right)$ (Fig. 1$)$. Here we examined the data from September 1994 to September 1997 for instruments located near levels with maximum AAIW and MW contributions, respectively at 800 and 1200 $\mathrm{m}$ (www.pangea.de). The temperature and salinity data were recalibrated with hydrographic data obtained during the mooring deployments, and the velocity data were low-pass filtered with a Butterworth filter with a cut-off period of 40 hours to eliminate high frequency motions. Two meddies were identified as passing by the mooring location, respectively in January-February 1995 (hereafter meddy E95) and in December 1995-January 1996 (henceforth meddy E96).

We also identified two Argo floats in the region north of the Canary Islands, with parking depth at $1000 \mathrm{dbar}$, which tracked two different meddies during several months (Fig. 2). Float position and hydrographic data flagged as good were downloaded from the Coriolis system (ftp://ftp.ifremer.fr/ifremer/argo). One of the floats tracked a meddy over a period of one year, between July 2004 and August 2005, and is henceforth called F04; the second float tracked a meddy at least between January and July 2007, and is henceforth called F07.

\section{METHODS}

The domain considered runs from 27 to $37^{\circ} \mathrm{N}$ and from $20^{\circ} \mathrm{W}$ to the African coastline. Observations prior to 1970 are removed, as well as any data value that does 


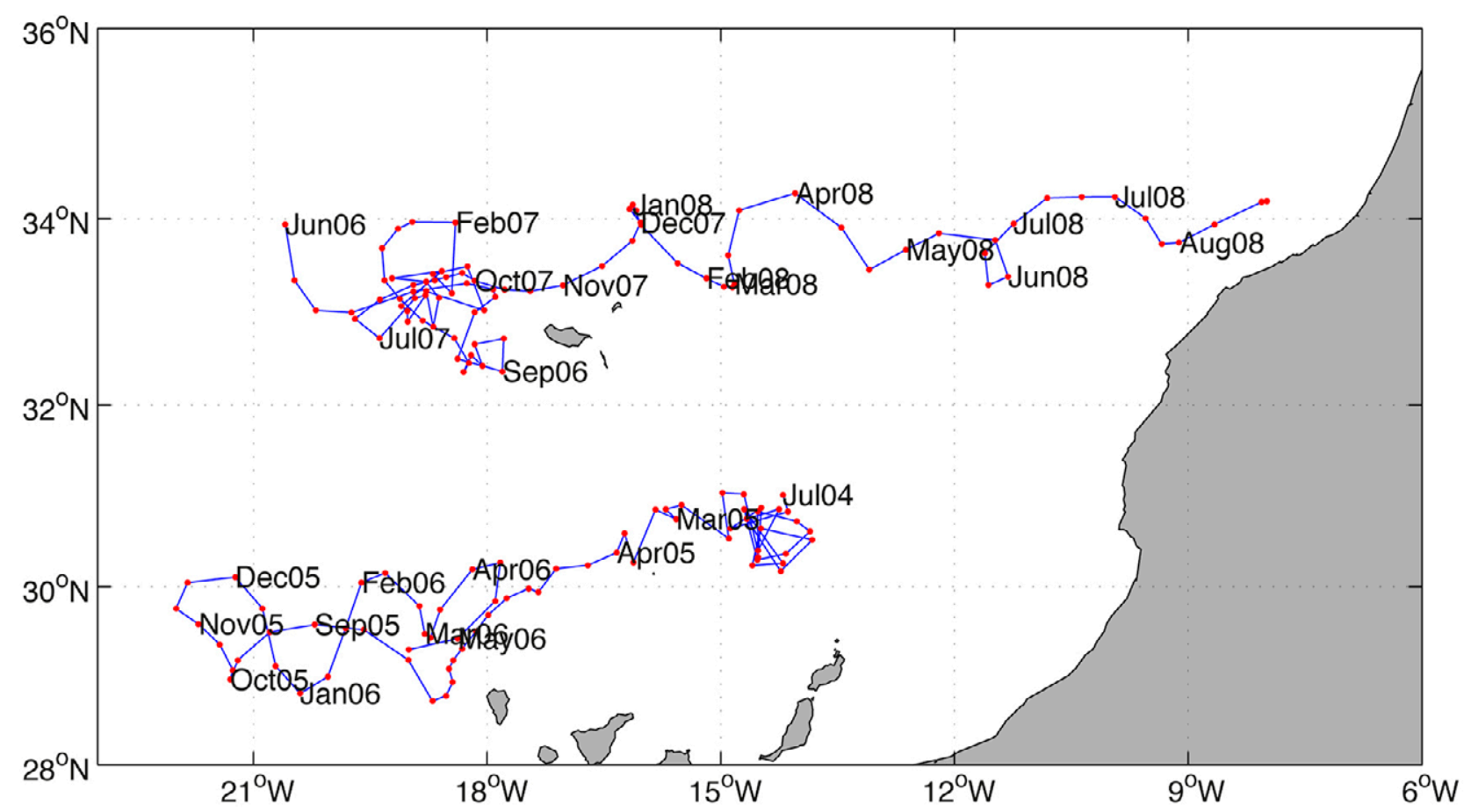

Fig. 2. - Trajectories of two Argo floats that tracked two meddies while drifting at $1000 \mathrm{dbar}$ in the region north of the Canary Islands; these meddies, which were initially detected and tracked in 2005 and 2007, are respectively named F04 and F07. The dots represent data points every time the float surfaced, approximately every 10 days, with the start of each calendar month annotated.

not meet all the following criteria: (1) they are flagged as good by NODC; (2) they satisfy a temperature and salinity range check $\left(-1<\mathrm{T}<40^{\circ} \mathrm{C}\right.$ and $\left.0<\mathrm{S}<41.3\right)$; (3) they are denser than observations above them (a density inversion test); and (4) they are consistent with the mean regional temperature-salinity relationship (estimated as the salinity value being within three standard deviations from the mean salinity for $0.5^{\circ} \mathrm{C}$ temperature bins over the entire region). The last criterion is repeated until the difference between two consecutive mean salinity values in each temperature bin is less than $10 \%$.

North Atlantic Central Waters (NACW) in the Canary Basin extend down to about $600 \mathrm{~m}$, with salinity values decreasing with depth down to 35.5 and phosphate concentrations increasing with depth up to $1.05 \mu \mathrm{mol} \mathrm{kg}{ }^{-1}$ (Pastor et al. 2012). AAIW are located immediately under the NACW (at the depth interval $600<\mathrm{z}<1000 \mathrm{~m}$ and the neutral-density interval $27.2<\gamma_{\mathrm{n}}<27.65 \mathrm{~kg} \mathrm{~m}^{-3}$ ), being recognizable through a salinity minimum (salinities are less than 35.5, or fresher than the deepest NACW) and an intense phosphate maximum (concentrations are well in excess of $1.25 \mu \mathrm{mol} \mathrm{kg}{ }^{-1}$ ) (Machín et al. 2006, Machín and Pelegrí 2009, Pastor et al. 2012). Meddies in the Canary Basin are located immediately below the AAIW level $\left(1000<\mathrm{z}<1500 \mathrm{~m}\right.$ and $\left.27.6<\gamma_{\mathrm{n}}<27.8\right)$ (Biescas et al. 2008), and are characterized by positive salinity anomalies (values as high as 36.5) and negative phosphate anomalies (concentrations as low as $0.7 \mu \mathrm{mol}$ $\mathrm{kg}^{-1}$ ) (Pastor et al. 2012).

Our meddy observations are within a region of strong MW influence, north of the Canary Islands. In this region the AAIW characteristics are significantly altered relative to the coherent tongue of AAIW to the south (Machín and Pelegrí 2009, Machín et al. 2010). Therefore, the presence of AAIW between the Canary Islands and the Iberian Peninsula must be identified via the existence of salinity values below a given threshold. To this end, we define the AAIW salinity for regional subdomains as values that fall below the 15th percentile of the historical observations at the intermediate-depth salinity minimum (Fig. 3). It turns out that, for the subdomain where we have identified all meddies, AAIW is characterized by salinities below 35.48 at temperatures above $8^{\circ} \mathrm{C}$. The corresponding maximum AAIW phosphate concentration, defined by the 85th percentile for phosphate at the salinity minimum, is $1.4 \mu \mathrm{mol} \mathrm{m}{ }^{-1}$.

\section{A PREPONDERANCE OF MEDDIES WITH FRESHWATER BERETS}

Given the above water mass definitions, we found six instances of interactions between meddies and AAIW in the Canary Basin: two through measurements at the ESTOC mooring (E95, E97), two through Argo floats drifting in the area (F04, F07), and two during the analysed hydrographic cruises (M37, GC07) (Table 1). In this section we briefly revise each of these cases. It is important to note here that these represent the totality of meddies that we came across when looking for examples, i.e. all meddies that we found in this region display some type of interaction. Hence, we may expect that there are many other instances of meddies where the MW-AAIW interplay takes place.

The two meddies at the ESTOC station have been previously reported by Machín and Pelegrí (2009), with meddy E95 passing by the mooring in January- 

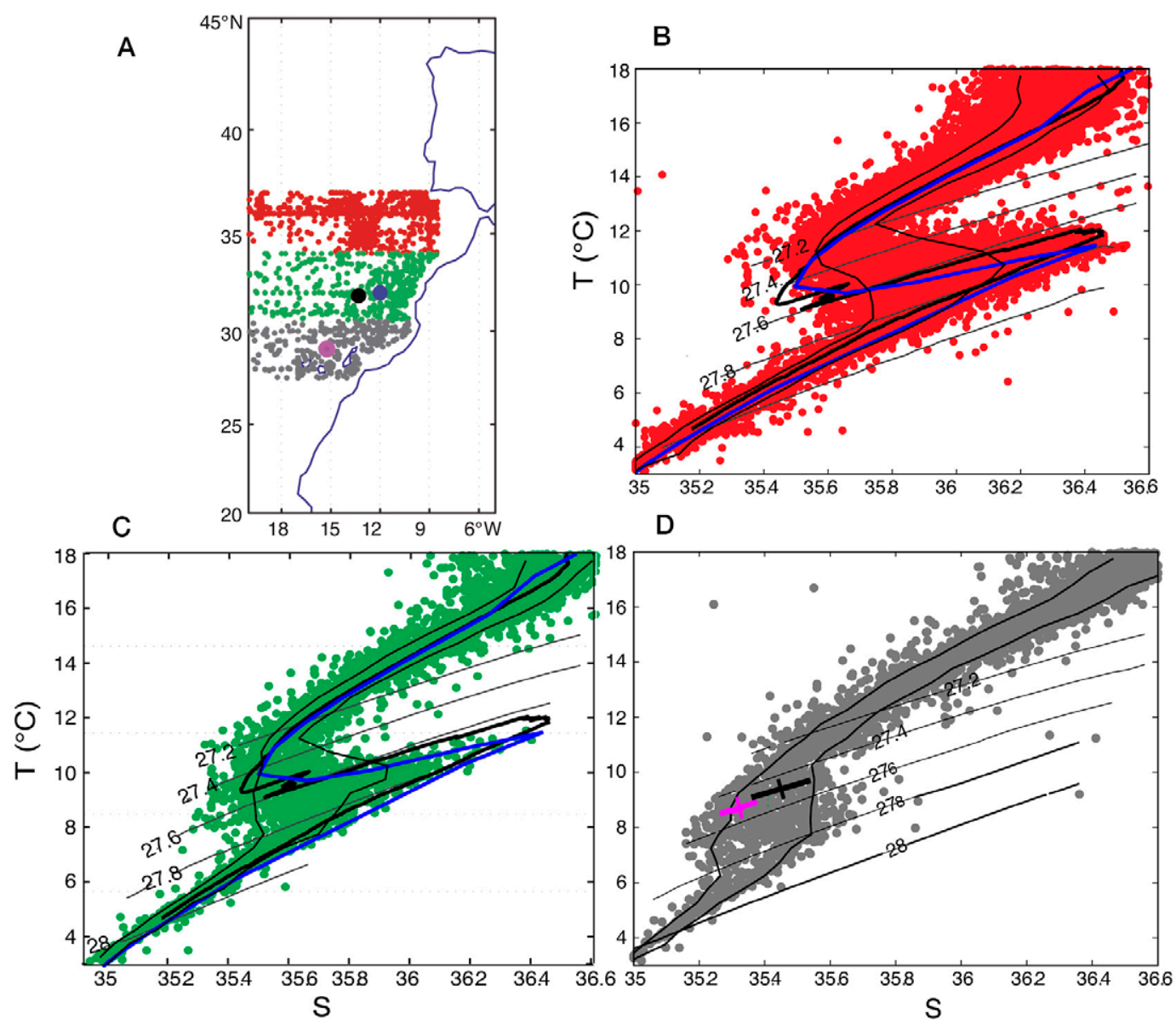

Fig. 3. - The hydrographic and ESTOC data for the Canary Basin are split into three different latitudinal domains, separated at 31 and $34^{\circ} \mathrm{N}$, from the coastline to $20^{\circ} \mathrm{W}$. A, the red, green and grey dots represent the locations of all NODC profiles in the northern Canary Basin that met our quality control checks; the large black and blue dots show the location of the GC07/M37 meddies, and the magenta dot situates the ESTOC station. B, potential-temperature salinity diagram for the northern domain: the historical hydrographic temperature-salinity data are plotted as red points, with the GC07/M37 meddies shown as thick black/blue lines; the thin black lines show the 15th and 85th percentile for the data, and several neutral-density lines are superimposed as thin grey lines. C, as for panel B but for the middle domain. D, as for panel B but for the southern domain; the black cross shows the mean value and standard deviation for salinity and temperature at $800 \mathrm{~m}$ for the entire ESTOC time series, and the magenta cross shows these values during the passage of E96 through the ESTOC station (between December 1995 and February 1996, when the $1200 \mathrm{~m}$ salinity exceeded 35.6); the temperatures and salinities recorded at $800 \mathrm{~m}$ during the passage of meddy E95 (not shown) are between the mean and E96 values.

February 1995 and meddy E96 contacting the mooring twice in December 1995-January 1996 (Fig. 4). The passage of the meddies is detected through the increase in salinity at $1200 \mathrm{~m}$, in excess of 36.0 or much higher than the 34.45 mean values at that depth, and also through the velocity increase at both 800 and $1200 \mathrm{~m}$, with peak values of $35 \mathrm{~cm} \mathrm{~s}^{-1}$ at $1200 \mathrm{~m}$ and slightly less at $800 \mathrm{~m}$. However, during the passage of both meddies, the salinity at $800 \mathrm{~m}$ showed an opposite behaviour, decreasing to values as low as 35.3 that are characteristic of AAIW (Fig. 3). The salinity decrease at $800 \mathrm{~m}$ occurs during the full time lapse when the salinity increases at $1200 \mathrm{~m}$ and the velocity intensifies at both water depths, indicating that the size of the overlying freshwater is similar to the size of the meddy (Fig. 4). A close inspection of the timing reveals that the salinity decrease at $800 \mathrm{~m}$ comes slightly ahead of the salinity increase at $1200 \mathrm{~m}$, hence suggesting that the low-salinity signal is located at the meddy's edge, like a ring or halo on top of the meddy.
It is important to note that the ESTOC station is located just north of the central Canary Islands, in a region of moderate influence of AAIW. At this location, the salinity minimum is located typically at 900 $\mathrm{m}$, with the 85 th percentile values in excess of 35.4 or larger than the minimum salinities detected at $800 \mathrm{~m}$ during the passage of either meddy (Machín and Pelegrí 2009). Therefore, these low-salinity covers cannot have a local source and are here interpreted to originate from a region closer to the continental slope, where the influence of AAIW was greatest.

The trajectories of the Argo floats that became trapped by two meddies are shown in Figure 2. One of these floats was deployed in July 2004 at $31^{\circ} \mathrm{N}, 15^{\circ} \mathrm{W}$, inside meddy F04, as shown by the positive salinity values between 1100 and $1300 \mathrm{~m}$ (Fig. 5A). The float remained within the meddy for over one year, until August 2005, displaying two quite different behaviours. Between July 2004 and January 2005 the meddy remained nearly stationary, in a region constrained by 


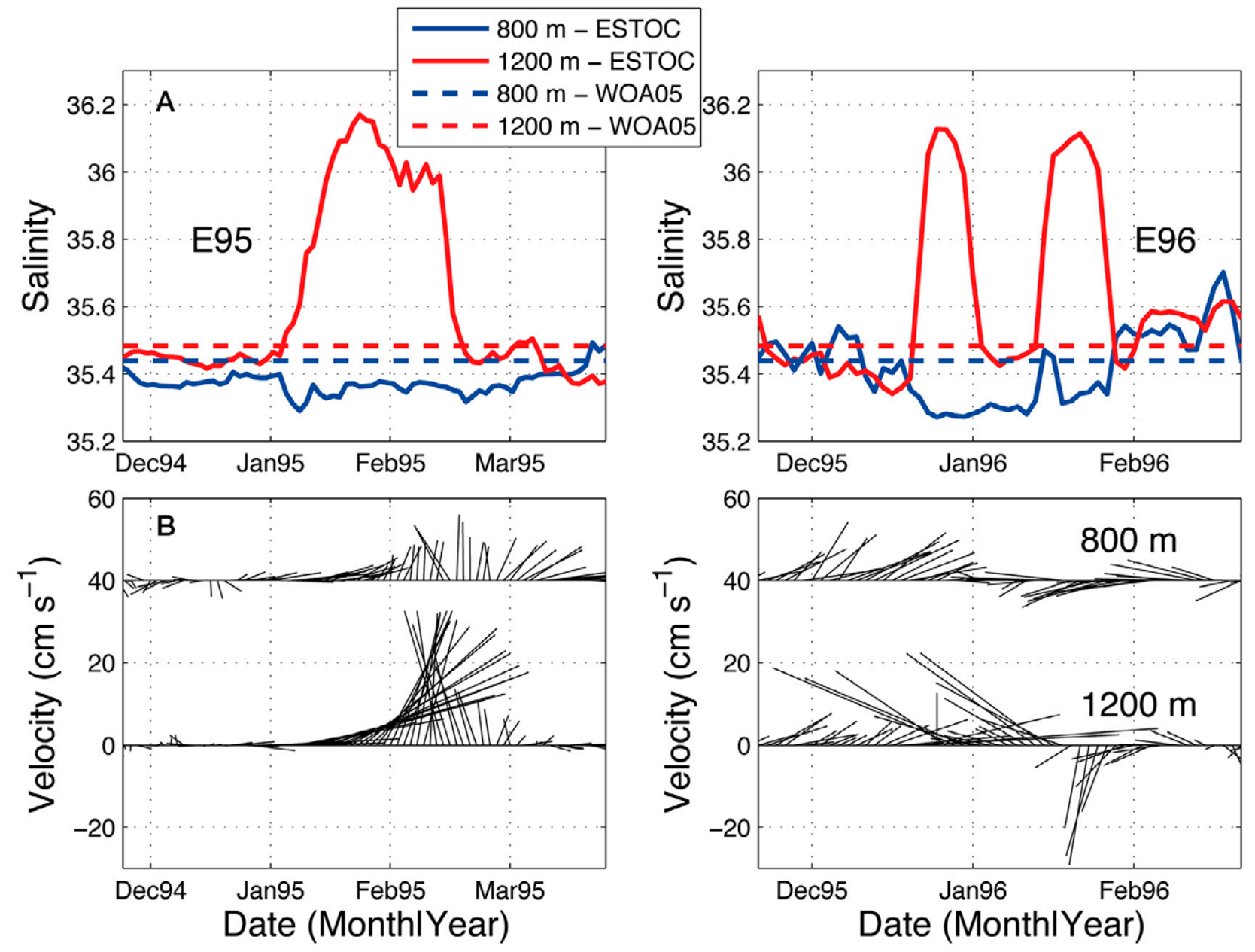

Fig. 4. - A, salinity at the ESTOC mooring at 800 (blue line) and $1200 \mathrm{~m}$ (red line), during selected periods; the climatological salinity values at 800 and $1200 \mathrm{~m}$ are drawn as dashed black and grey lines, respectively. B, velocity for the same depths and time periods. Note that the zero velocity level is displaced to $40 \mathrm{~cm} \mathrm{~s}^{-1}$ for the time series at $800 \mathrm{~m}$. The data corresponding to meddy E95 are shown in the left panels and the data for meddy E96 are shown on the right panels.
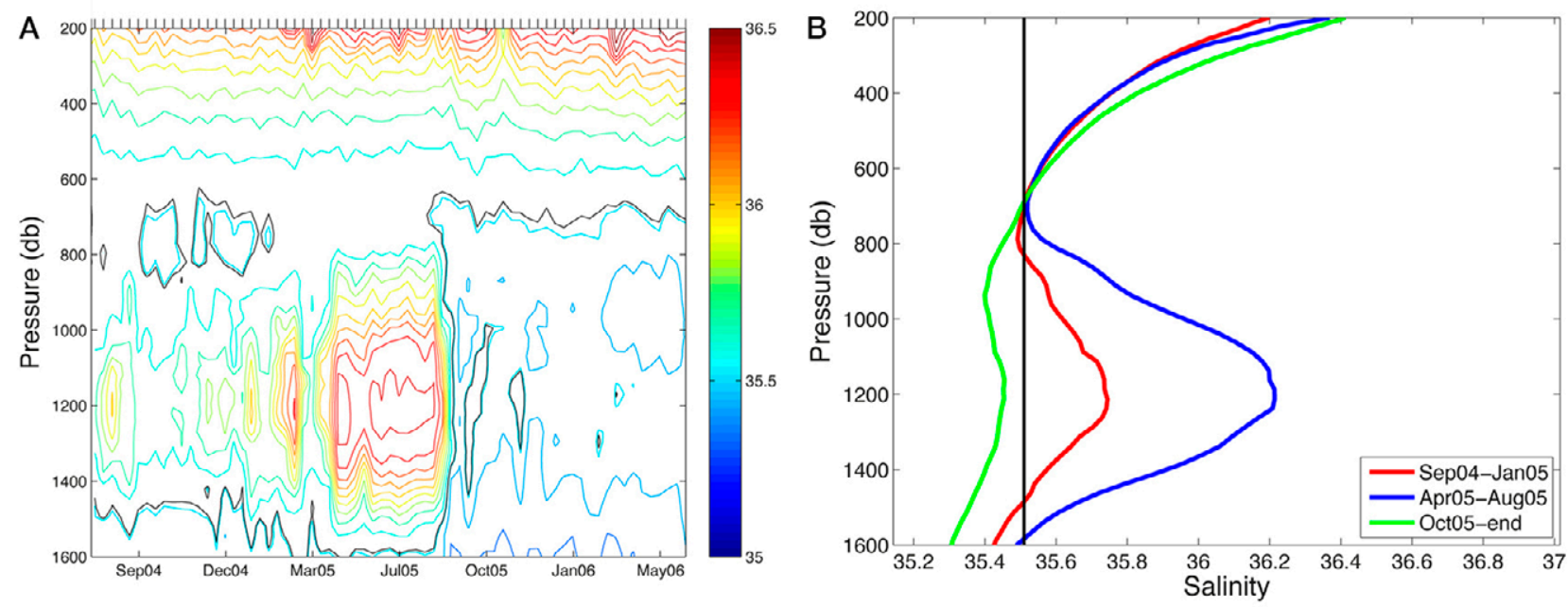

Fig. 5. - Salinities sampled by the float that tracked meddy F04. A, time-depth distribution. B, mean depth-salinity distributions grouped for three different periods as indicated; the vertical line corresponds to the salinity value of the deepest NACW. 

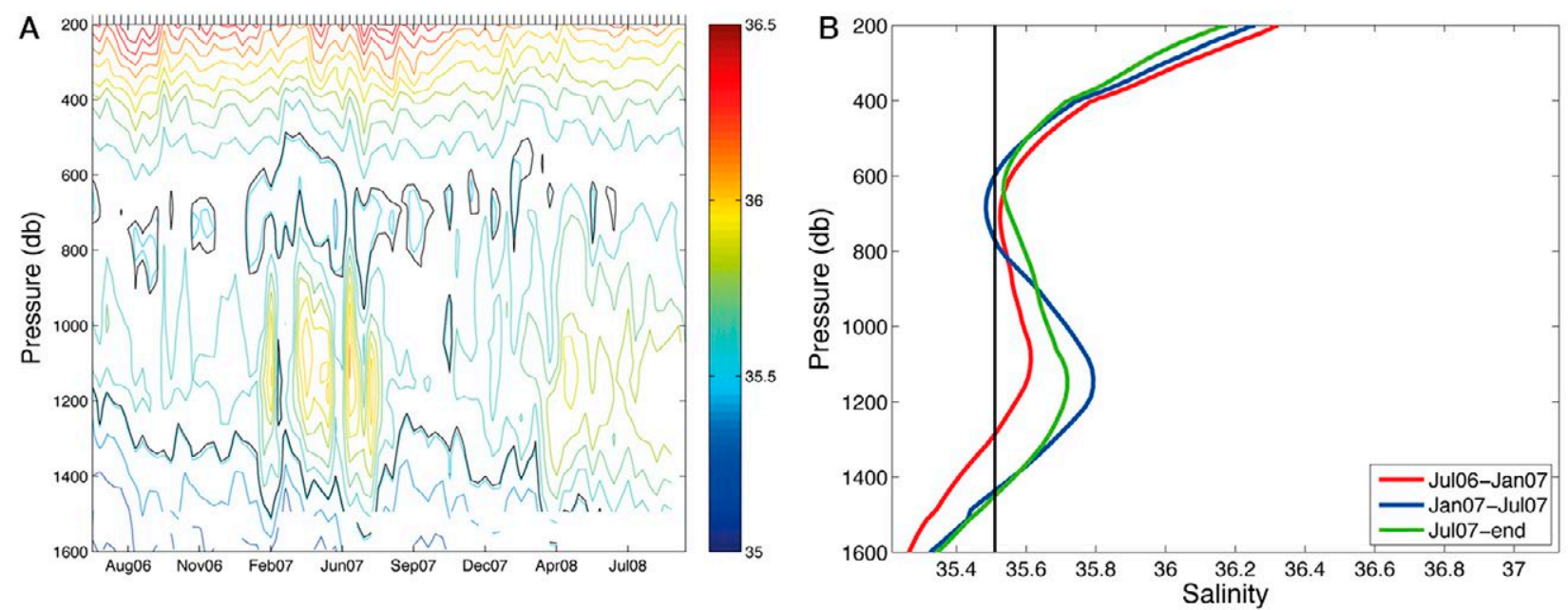

Fig. 6. - Salinities sampled by the float that tracked meddy F07. A, time-depth distribution. B, mean depth-salinity distributions grouped for three different periods as indicated; the vertical line corresponds to the salinity value of the deepest NACW.

several seamounts: the Dacia Seamount to the north, at $31.2^{\circ} \mathrm{N}, 13.7^{\circ} \mathrm{W}$, and several other seamounts to the south and southeast.

During this initial period the float followed an anticyclonic motion and the salinities at $1100-1300 \mathrm{~m}$ remained moderate (barely in excess of 36.0); interestingly, at these times the float measured salinity minima (less than 35.5) at about 750-800 m. In January 2005 the float began a quite steady westward translation that reached $21^{\circ} \mathrm{W}$ by December 2005, before backing east; the high salinities in the 1100-1300 m depth range were only observable until September 2005, clearly proving that at this time the float left the meddy. During the time when the float moved west and remained inside the meddy, the positive salt anomalies occupied a thick layer $(800-1500 \mathrm{~m})$ and reached maximum values of about 36.5 , indicating that the float had moved closer to the meddy core, and the overlying low-salinity values disappeared.

The depth-salinity profiles for the float that sampled meddy F04 may be grouped as follows: while the float remained at F04's edge (September 2004 to January 2005), when it stayed near the meddy's centre (April to August 2005), and after it left F04 (October 2005 to June 2006) (Fig. 5B). The profiles above the meddy were very much alike between September 2004 and August 2005, though the relatively fresh overlying waters were not detectable while the float moved near the meddy's centre. When the float left the meddy, the salinity displayed a minimum of less than 35.4 at 1000 $\mathrm{m}$, illustrative of the presence of AAIW at this level and latitudes $\left(29-30^{\circ} \mathrm{N}\right)$.

The second Argo float was deployed on July 2006 at $34^{\circ} \mathrm{N}, 19^{\circ} \mathrm{W}$ and in late January 2007 it became trapped by the nearby F07 meddy (Fig. 6A). The float remained inside the meddy until August 2007, as proved by the positive salinity anomalies located between 850 and $1300 \mathrm{~m}$. Shortly after leaving the meddy, the float moved east quite swiftly until late August 2008, when it reached the continental slope at about $34^{\circ} \mathrm{N}, 8^{\circ} \mathrm{W}$. The moderate amplitude and thickness values for the positive salt anomalies suggest that the float remained near the meddy's edge between February and July 2007; interestingly enough, as happened with the float that tracked meddy F04, at this time a halo of low-salt values became evident at $700 \mathrm{~m}$.

The depth-salinity profiles for the float that sampled meddy F07 are again grouped in three periods: previous to entering the meddy (July 2006 to January 2007), as it remained on the meddy's edge (January to July 2007), and after it left the meddy and moved towards the coast along $34^{\circ} \mathrm{N}$ (August 2007 to August 2008) (Fig. 6B). Interestingly, the salinity on top of those profiles taken between January and July 2007 (while the float remained at the meddy's edge) reached values below 35.5, actually smaller than after the float left the meddy. This suggests that these low-salinity waters were trapped on top of the meddy at an earlier time, in a region where the overlying waters had a higher AAIW content, likely at latitudes lower than $34^{\circ} \mathrm{N}$.

Despite their location north of the ESTOC station, the M37 and GC07 meddies showed similar low-salinity waters overlying the salt lenses (Fig. 7). These meddies have a high-salinity core of nearly 36.5 , with an anticyclonic rotation that characterizes meddies, and with the velocities close to zero at the core and increasing to more than $0.5 \mathrm{~m} \mathrm{~s}^{-1}$ at its flanks (Fig. 7). The anticyclonic rotation of M37 extended up to the surface, while the GC07 meddy had the more classical dipole-like structure, where the azimuthal velocities extend above and below the meddy's core but decay to zero near the sea surface.

A relatively low-salinity stratum was observed on top of both M37 and G07, in the $27.2<\gamma_{\mathrm{n}}<27.5 \mathrm{~kg} \mathrm{~m}^{-3}$ density range. This salinity minimum extended along the entire length of both hydrographic sections, but it was noticeably fresher directly above and on the fringes of each meddy. The phosphate concentration (Fig. 7 , lower panels) further illustrates the contrast between the meddy core and beret: low values were observed in the meddies' core and anomalously high values immediately on top of both meddies, particularly on top of GC07. Thus, as illustrated in Figure 7, these interactions show double anomalies: the highly salty 


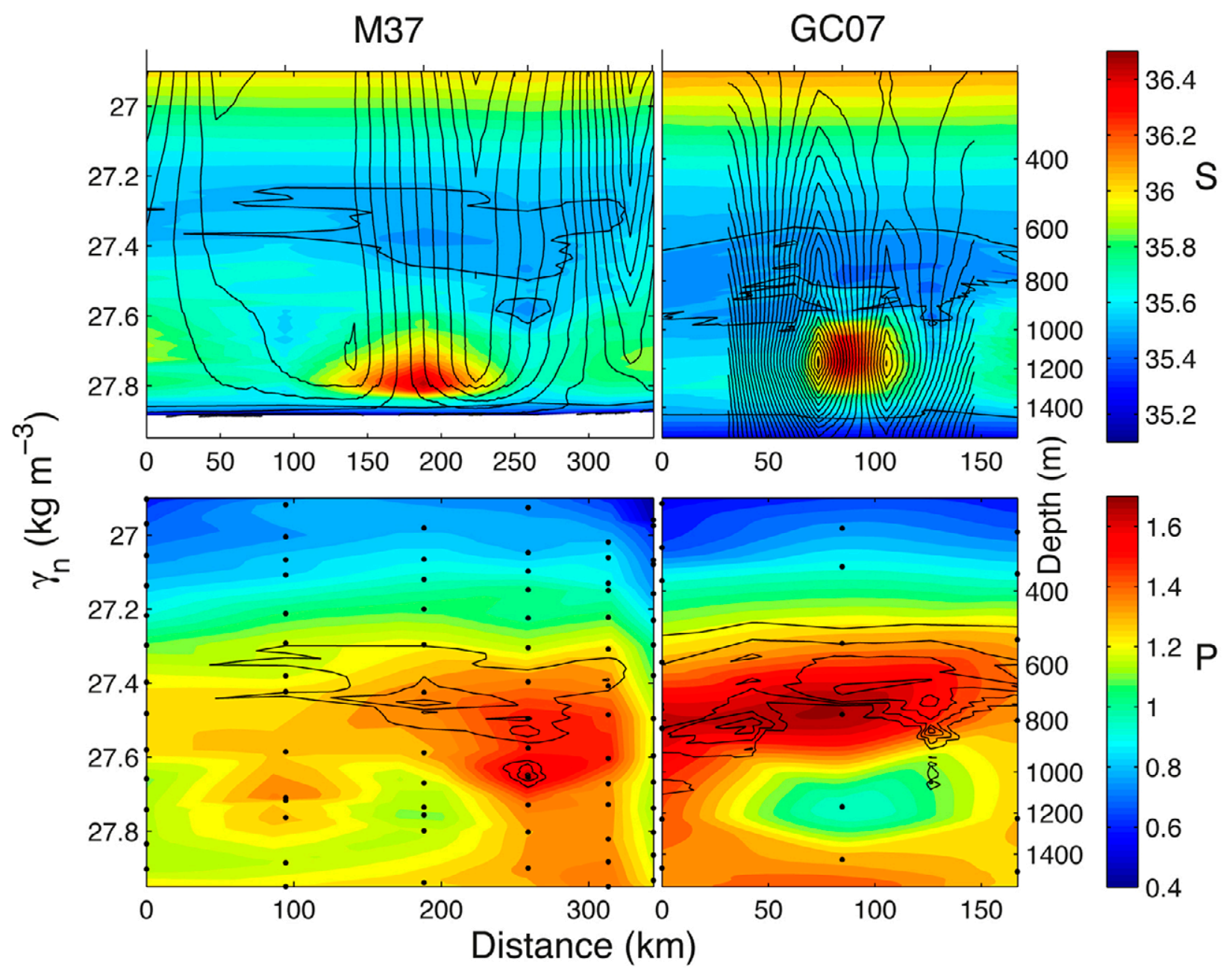

Fig. 7. - Salinity (upper panels) and phosphate ( $\mu \mathrm{mol} \mathrm{kg} \mathrm{kg}^{-1}$, lower panels) distributions as a function of neutral density and horizontal distance along the two hydrographic sections that sampled meddies M37 (left panel) and GC07 (right panel) (see their locations in Fig. 1); approximate depths are indicated on the right-hand axis. The contours represent the geostrophic velocity (cm s ${ }^{-1}$, upper panels) and the AAIW contribution $(\%$, lower panels).

and nutrient-poor values at the meddy core were accompanied by weakly-fresh and nutrient-rich values on top of the meddy; such low-salinity and rich-phosphate concentrations point towards AAIW as the source water for the overlying layers. In particular, the temperature-salinity relationship for the freshwater berets were far outside the expected range of values in the meddy formation region (Fig. 3B), and were just below the 15 th percentile for salinity in the region in which they were found (Fig. 3C-D). The berets actually resembled the salinity minimum in the southernmost subregion, as shown in Fig. 3D, raising the possibility that the meddies entrained the northward-advected AAIW as they meandered south of the region where they were detected, as discussed next.

\section{DISCUSSION}

The hydrographic sections and ESTOC measurements offer a Eulerian view of the meddies while the Argo floats offer a Lagrangian perspective. None of them is a complete sight, as in all cases sampling takes place in some unknown location inside the meddy, but they provide complementary views: the cruises represent a rapid dissection, the moorings sample the slowly travelling meddy, and the floats follow the meddy for a relatively long period of time. In all cases, however, it is clear that the meddy is covered by AAIW water, with maximum concentrations frequently on the meddy's edge.

The ESTOC station is located close to the Canary Islands, in the southern part of our study region, hence under the influence of AAIW (Machín and Pelegrí 2009). For this reason the waters sampled at $800 \mathrm{~m}$ at the ESTOC station often had salinities of less than 35.4, particularly during the autumn and winter seasons (Fig. 4). Nevertheless, it is noteworthy that the minimum salinity values observed between September 1994 and September 1997 corresponded to the periods when the meddies were detected at the $1200 \mathrm{~m}$ level. This finding suggests that, before reaching the ESTOC station, the meddies must have travelled through a region with greater AAIW influence, possibly in the region immediately north of the Canary Islands and close to the continental slope. In particular, the salinity signature reached minimum values just as meddy E95 entered (in 
early January 1995) or departed from (in late February 1995) the ESTOC station (Fig. 4), consistent with the idea that the highest AAIW contribution takes place on top the meddy's edge. The GC07 and M37 meddies were detected some $300 \mathrm{~km}$ north of the ESTOC station, in a region of much less AAIW influence. In the vertical property distributions, M37 appears thinner than GC07 in depth and density but wider in the horizontal (Fig. 7). One possibility is that M37 was indeed larger than GC07, yet M37 was sampled near its edge, while GC07 was sampled closer to its core. The signature of AAIW (low salinities and high nutrients) was clear on top of both meddies, standing out against the background conditions (Fig. 3).

Finally, the meddies sampled by the floats were located at two different latitudes: F04 moved between 29 and $31^{\circ} \mathrm{N}$ while $\mathrm{F} 07$ was located close to $34^{\circ} \mathrm{N}$. For this reason the salinities on top of F04 were barely distinguishable from the salinities of surrounding waters at the same level, while the salinities on top of F07 were significantly lower than those of the neighbouring waters, hence indicating a greater AAIW contribution; furthermore, the minimum salinities for F07 corresponded to the time during which it sampled the meddy's edge.

The above distributions of salinity, phosphate and velocity support the idea that the water composition on top of a meddy is the outcome of its travelling between regions with and without AAIW. A key consideration is that a meddy does not travel as an isolated feature but strongly influences the waters above and below (Siedler et al. 2005, Bashmachnikov and Carton 2012), to the point that a substantial portion of the water column moves almost jointly with the meddy, behaving very like a Taylor column (Pedlosky 1979, e.g.). However, the water on top of the meddy does not behave as a perfect Taylor column, as otherwise these waters would remain unchanged from the location where the meddy was originally formed, i.e. the horizontal velocity field does change with depth as a result of both baroclinicity and diffusion.

Shortly after formation, in the Gulf of Cadiz, a meddy is entirely embedded within MW. If a meddy travels south enough, it will reach a region where its upper layers become enclosed by AAIW, which can then be progressively incorporated on top of the meddy through diffusive processes. As this same meddy leaves the region with AAIW influence, its covering waters will conserve this fraction of AAIW until, after a sufficiently long time period, it becomes diluted with the surrounding waters, again through diffusion. Hence, the amount of AAIW in a water layer overlying the meddy depends on three time scales: (1) an advective time scale, $\mathrm{T}_{\mathrm{a}}$, or the time the meddy spends travelling through some water stratum; (2) a diapycnal diffusive time scale, $T_{d}$, or the time that the meddy's properties take to affect this layer; and (3) an epipycnal diffusive time scale, $\mathrm{T}_{\mathrm{e}}$, or the time that this layer takes to exchange these properties laterally with the surrounding waters.

Let us next estimate the order of magnitude of these time scales. The first stage, i.e. the incorporation of AAIW on top of the meddy, depends on the time the meddy spends on waters with AAIW content. This is the advective time scale, which is a function of both the horizontal extent of the AAIW layer that is transited by the meddy, $\mathrm{L}=200$ to $500 \mathrm{~km}$, and the drift velocity of the meddy, $\mathrm{U}=0.02 \mathrm{~m} \mathrm{~s}^{-1}$ (as deduced from the data plotted in Fig. 2). Hence, a reasonable estimate is $T_{a}$ $=\mathrm{L} / \mathrm{U}=3$ to 17 months. As the meddy returns north, it will start exchanging with the surrounding waters the AAIW that it has incorporated on top, possibly with no time limitation.

A second scale corresponds to the time it takes the MW inside the meddy to influence a layer located at a distance $\mathrm{h}$ on top. This diffusive time scale is given by $T_{d}=\operatorname{sh}^{2} / K_{v}$, where $K_{v}$ is the vertical diffusion coefficient and $\mathrm{s}$ is a factor that depends on the fraction of the property that is transferred to the adjacent layer (e.g. Batchelor 1977, p. 190). For the MW characteristics to become recognizable in the overlaying layer, we choose $s=1$, which gives the time when $50 \%$ of the meddy's salt anomaly reaches a distance $h$ above it.

Using $\mathrm{K}_{\mathrm{v}}=10^{-5} \mathrm{~m}^{2} \mathrm{~s}^{-1}$, as reported by Ledwell et al. (1998) for the eastern subtropical Atlantic, we obtain $\mathrm{T}_{\mathrm{d}}=4$ and 15 months for $\mathrm{h}=10$ and $20 \mathrm{~m}$, respectively. The actual $\mathrm{K}_{\mathrm{v}}$ value is likely to change depending on the radial distance to the axis of rotation, because the azimuthal velocity will increase up to a maximum near the meddy's edge (Fig. 7). On top of the edge we usually find the maximum vertical velocity gradients and, hence, the largest $\mathrm{K}_{\mathrm{v}}$ and smallest $\mathrm{T}_{\mathrm{d}}$ values.

Finally, as the meddy either enters the region where its upper layers are in contact with AAIW or returns to the region where it is in contact with MW and North Atlantic Deep Water, these layers will exchange water with the surrounding fluid. The time required for this to effectively take place is the epipycnal diffusive time scale, which depends on the horizontal diffusion coefficient, $K_{h}$, and the distance to be affected by the exchange. If the exchange is to affect an outer ring of width $2 b$ on top of the meddy, the time scale is given by $T_{e}=s^{2} / K_{h}$. A sensible choice is $K_{h}=10 \mathrm{~m}^{2} \mathrm{~s}^{-1}$, again from Ledwell et al. (1998), and for a ring of width $2 \mathrm{~b}=20 \mathrm{~km}$ it gives $\mathrm{T}_{\mathrm{e}}=4$ months (for $\mathrm{s}=1$ ). Notice that $\mathrm{K}_{\mathrm{h}}$ becomes substantially reduced immediately on top of the edge of the meddy (Law et al. 2001), implying much longer $T_{e}$ values, but this is probably not the case several tens of metres above the meddy.

In summary, as the meddy is advected below the AAIW water stratum during 3-17 months, the immediately overlying layers (less than an order of $10 \mathrm{~m}$ ) will become saltier because of vertical diffusion from the meddy, but those located further above will freshen as a result of lateral diffusion of AAIW. The first waters to be influenced by this lateral diffusion will be those at the rim of the eddy, hence the frequent observation of the halo-like structure. However, if the meddy remains long enough inside the AAIW strata, the entire overlying layers will be covered, turning the halo into a beret. By the time the meddy leaves the region of AAIW influence it will carry its halo or beret of rotating AAIWs to regions far in the North Atlantic Ocean, where it will be slowly eroded through diffusive processes. The diffusive process will reverse, the outer edge of the 


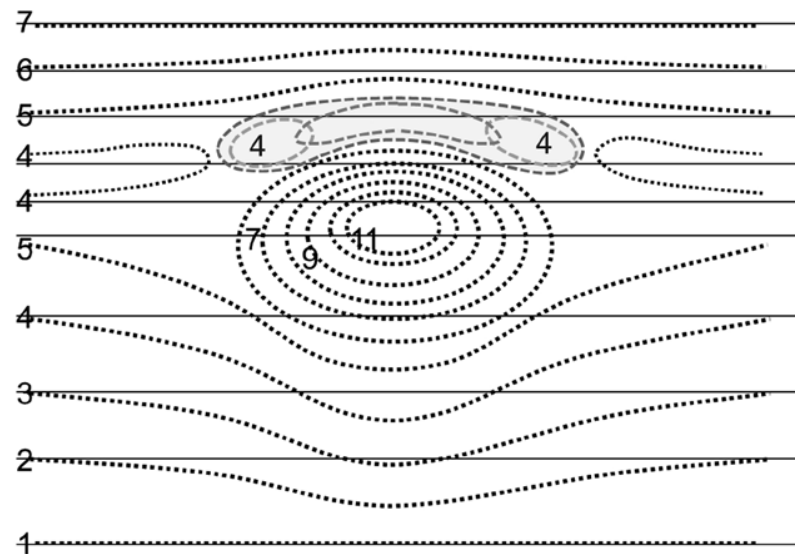

Fig. 8. - Schematic diagram on how the salinity distribution becomes modified by the presence of a meddy (contours represent isohalines, with the numbers indicating a relative level of salt content). In the absence of a meddy, the isohalines are approximately horizontal with a well-defined minimum at the AAIW level (solid lines). The appearance of the meddy (dotted lines) brings a large positive salt anomaly immediately below the minimum AAIW salinity level but the overlaying layers are not immediately affected but progressively incorporate the low-salinity waters through diffusion, first showing up as a halo and eventually as a beret. When the meddy returns back north, to the region with no AAIW influence, the beret of low-salinity waters will progressively erode, from its edges towards the centre (the dashed lines illustrate the progression of states, from light to dark grey colours as time proceeds).

meddy being the first to lose its AAIW content (Fig. 8).

\section{CONCLUDING REMARKS}

The interaction of coherent ocean vortices with various water masses has long been observed near the ocean's surface. For example, warm Agulhas rings entrain cold water from the Benguela upwelling system on their flanks and advect upwelled water far offshore as long filaments (Lutjeharms et al. 1991). Likewise, warm core rings shed from the Gulf Stream and advected into the northern recirculation gyre often entrain shelf water, slope water, and/or Gulf Stream water on their fringes, creating important onshore and offshore fluxes of very diverse water masses-and their associated heat, freshwater and biogeochemical contents (Nof 1988, Ryan et al. 2001).

Here we have reported a related but quite different feature. A meddy, during its trip through regions near the Canary Islands, may often encounter AAIW. Property-property plots (Fig. 3), time series (Fig. 4), and property transects (Fig. 7) have shown that meddies found in the neighbouring northern region display the signal of AAIW on top.

The analysis of the characteristic advective and diffusive times indicates that the trapping of AAIW on top likely takes place through epipycnal diffusion. As the meddy returns to latitudes where AAIW is not present, the southern waters will show up distinctly against the background field as a halo or beret of fresh and nutrient-rich characteristics on top of the meddy.

Meddies are long-lived mesoscale structures that travel far from their source, helping to spread the MW signature over the entire North Atlantic Ocean (Rich- ardson et al. 2000). Hence, the association of AAIW with meddies may also be a significant mechanism for the effective dispersion for this southern water mass.

\section{ACKNOWLEDGEMENTS}

This work was supported by the projects CANOA (CTM2005-00444/MAR), TIC-MOC (CTM201128867) and VA-DE-RETRO (CTM2014-56987-P), funded by the Spanish government. We thank Pangea (http://www.pangaea.de/) for making freely available the ESTOC current meters and CANOA hydrographic data. The U.S. National Oceanic Data Centre is also gratefully acknowledged for providing historical hydrographic data (at http://www.nodc.noaa.gov/OC5). FM was partly supported by the Spanish Ministry of Education and Science through the Juan de la Cierva Programme. We wish to thank Jaime Palter, Mike McCartney and two anonymous reviewers for a number of constructive comments and suggestions that have improved the quality of the final manuscript. This article is dedicated to three excellent people and admirable oceanographers: Jordi Font, Marta Estrada and Jordi Salat.

\section{REFERENCES}

Armi L., Hebert D., Oakey N., et al. 1988. The history and decay of a Mediterranean salt lens. Nature 333: 649-651. http://dx.doi.org/10.1038/333649a0

Armi L., Hebert D., Oakey N., et al. 1989. Two years in the life of a Mediterranean salt lens. J. Phys. Oceanogr. 19: 354-383. http://dx.doi.org/10.1175/1520-0485(1989)019<0354:TYITLO $>2.0 . \mathrm{CO} ; 2$

Bashmachnikov I., Carton X. 2012. Surface signature of Mediterranean water eddies in the northeastern atlantic: effect of the upper ocean stratification. Ocean Sci. 8(6): 931-943. http://dx.doi.org/10.5194/os-8-931-2012

Batchelor G. 1977. An Introduction to Fluid Dynamics, Cambridge Univ. Press.

Biescas B., Sallarès V., Pelegrí J.L., et al. 2008. Imaging meddy finestructure using multichannel seismic reflection data. Geophys. Res. Lett. 35: L11609. http://dx.doi.org/10.1029/2008GL033971

Bower A., Armi L., Ambar I. 1997. Lagrangian observations of meddy formation during a Mediterranean underwater seeding experiment. J. Phys. Oceanogr. 27: 2545-2575. http://dx.doi.org/10.1175/1520-0485(1997)027<2545:LOOMF D>2.0.CO;2

Hedstrom K., Armi L. 1988. An experimental study of homogeneous lenses in a stratified rotating fluid. J. Fluid Mechanics 191: 535-556. http://dx.doi.org/10.1017/S0022112088001697

Jackett D., McDougall T. 1997. A neutral density variable for the world's oceans. J. Phys. Oceanogr. 27: 237-263. http://dx.doi.org/10.1175/1520-0485(1997)027<0237:ANDVF $\mathrm{T}>2.0 . \mathrm{CO} ; 2$

Law C., Martin A., Liddicoat M., et al. 2001. A Lagrangian sf 6 tracer study of an anticyclonic eddy in the North Atlantic: patch evolution, vertical mixing and nutrient supply to the mixed layer. Deep-Sea Res. II 48(4): 705-724. http://dx.doi.org/10.1016/S0967-0645(00)00112-0

Ledwell J., Watson A., Law C. 1998. Mixing of a tracer in the pycnocline, J. Geophys. Res. 103(C10): 21499-21529. http://dx.doi.org/10.1029/98JC01738

Louarn E., Morin P. 2011. Antarctic intermediate water influence on Mediterranean Sea water outflow, Deep-Sea Res. I 58(9): 932-942. http://dx.doi.org/10.1016/j.dsr.2011.05.009

Lutjeharms J.R.E., Shillington F.A., Duncombe-Rae C.M. 1991. Observations of extreme upwelling filaments in the Southeast Atlantic Ocean. Science 253: 774-776. 
http://dx.doi.org/10.1126/science.253.5021.774

Machín F., Hernández-Guerra A., Pelegrí J.L. 2006. Mass fluxes in the Canary Basin. Prog. Oceanog. 70(2-4): 416-447. http://dx.doi.org/10.1016/j.pocean.2006.03.019

Machín F., Pelegrí J.L. 2009. Northward penetration of Antarctic Intermediate Water off Northwest Africa. J. Phys. Oceanogr. 39(3): 512-535.

http://dx.doi.org/10.1175/2008JPO3825.1

Machín F., Pelegrí J.L., Fraile-Nuez E., et al. 2010. Seasonal flow reversals of intermediate waters in the canary current system east of the Canary Islands. J. Phys. Oceanogr. 40(8): 1902-1909. http://dx.doi.org/10.1175/2010JPO4320.1

McDowell S.E., Rossby H.T. 1978. Mediterranean water: An intense mesoscale eddy off the Bahamas. Science 202: 1085-1087. http://dx.doi.org/10.1126/science.202.4372.1085

Nof D. 1988. The propagation of 'streamers' along the periphery of warm-core rings. Deep-Sea Res. 35: 1483-1498. http://dx.doi.org/10.1016/0198-0149(88)90098-2

Parrilla G., Neuer S., Le Traon P.-Y., et al. 2002. Topical studies in oceanography: Canary Islands Azores Gibraltar Observations (CANIGO). Volume 1: Studies in the northern Canary Islands basin. Deep-Sea Res. II 49: 3409-3413.

http://dx.doi.org/10.1016/S0967-0645(02)00104-2
Pastor M., Peña-Izquierdo J., Pelegrí J.L., et al. 2012. Meridional changes in water mass distributions off NW Africa during November 2007/2008. Cienc. Mar. 38(1B): 223-244. http://dx.doi.org/10.7773/cm.v38i1B.1831

Pedlosky J. 1979. Geophysical Fluid Dynamics. Springer-Verlag. New York. http://dx.doi.org/10.1007/978-1-4684-0071-7

Richardson P., Bower A., Zenk W. 2000. A census of Meddies tracked by floats. Prog. Oceanog. 45: 209-250. http://dx.doi.org/10.1016/S0079-6611(99)00053-1

Ryan J.P., Yoder J.A., Townsend D.W. 2001. Influence of a Gulf Stream warm-core ring on water mass and chlorophyll distributions along the southern flank of Georges Bank. Deep-Sea Res. II 48: 159-178. http://dx.doi.org/10.1016/S0967-0645(00)00117-X

Siedler G., Armi L., Müller T.J. 2005. Meddies and decadal changes at the Azores Front from 1980 to 2000. Deep-Sea Res. II 52(34): 583-604 http://dx.doi.org/10.1016/j.dsr2.2004.12.010

Tsuchiya M., Talley L., McCartney M. 1992. An eastern Atlantic section from Iceland southward across the Equator. Deep-Sea Res. 39(11/12A): 1885-1917. 